\title{
Komnas HAM Indonesia Kedudukan dan Perannya dalam Struktur Ketatanegaraan Indonesia
}

\author{
Sri Hastuti Puspitasari
}

\begin{abstract}
The need about indenpendency of National Commission for Human Rights is crucial. If we see however the existence of National Commission fo Human Rights in Indonesia, the existence of independency is very apprehensive, both juridical aspect and non-juridical. Therefore, by completing the law regulation which are able to accommodate the lack of this condition must be put into action immediately. By the expectation, the effort of constructing the National Commission for Human Rights's task could be brought into reality.
\end{abstract}

\section{Pendahuluan}

Kehadiran sebuah lembaga independen yang lahirnya dibidani oleh Presiden selalu menghadirkan pesimisme. Demikian situasi yang mewarnai kelahiran Komnas HAM melalui Keputusan Presiden. Beberapa kalangan meragukan independensi kinerja Komnas HAM, sebab pelanggaran HAM di Indonesia justru banyak melibatkan negara.' Komnas HAM mula-mula ditunjuk dan menjalankan tugasnya berdasarkan Keputusan

Presiden Nomor 50 tahun 1993 tanggal 7 Juni 1993. Tujuan pembentukan Komnas HAM adalah untuk membantu mengembangkan kondisi yang kondusif bagi pelaksanaan HAM di Indonesia sesuai dengan Pancasila, UUD 1945, Piagam PBB, serta Deklarasi Universal Hak Asasi Manusia. Selain itu, Komnas HAM dibentuk untuk tujuan meningkatkan periundungan HAM guna mendukung terwujudnya pembangunan nasional. ${ }^{2}$ Berdasarkan Keppres tersebut,

1 Sebuah penelitian yang dilakukan oleh Comelis Lay dan Pratikno menunjukkan argumentasi yang cukup tajam bahwa pelanggaran HAM di Indonesia banyak melibatkan negara sebagai pelaku utamanya. Akan sulit melakukan.penegakan hukum atas pelanggaran HAM oleh lembaga yang didirikan atas prakarsa penguasa negara. Cornelis Lay dan Pratikno, Komnas HAM di bawah Rezim Otoritarian (Yogyakarta: Fisipol UGM, 1998).

${ }^{2}$ Tujuan ini menjadi semacam legitimasi politik bagi pemerintah. Seperti yang digambarkan oleh Jessica M.R.Smith dalam penelitiannya,situasi yang meliputi awal 1990-an terjadi perubahan politik, ekonomi dan sosial yang menghendaki adanya keharusan perlindungan HAM sebagai legitimiasi politik bagi pemerintah. Di samping 
Komnas melakukan berbagai kegiatan, antara lain menyebarluaskan wawasan nasional dan Internasional tentang HAM kepada masyarakat luas, mengkaji berbagai instrumen perlindungan HAM dari PBB dan memberikan saran tentang kemungkinan akses dan ratifikiasinya serta serta melaksanakan pemantauan, penyelidikan dan pemajuan perlindungan $\mathrm{HAM}^{3}$

Organisasi Komnas HAM dilengkapi dengan 2 (dua) badan kelengkapan. Pertama, Sịdang Paripuma, yang merupakan kekuasaan tertinggi Komnas HAM dan terdiri dari seluruh anngota Komnas HAM. Dalam forum ini ditetapakan Program Kerja, Mekanisme Kerja serta Peraturan Tata Tertib Komnas HAM. Kedua adalah Subkomisi yang terdiri dari Subkomisi Pendidikan dan Penyuluhan, Subkomisi Pengkajian Instrumen HAM dan Subkomisi Pemantauan Pelaksanaan HAM. Setiap Subkomisi terdiri dari paling banyak 9 (sembilan) orang yang terdiri dari Ketua, Wakil Ketua dan Anggota, dibantu oleh staf pendukung kerja subkomisi. Untuk mendukung kegiatan organisasi, di Komnas HAM dilengkapi dengan Sekretriat Jenderal sebagai unsur pelaksana dan pelayanan kerja Komnas HAM. Sejak tahun 1999, Komnas dibantu oleh seorang Direktur Esekutif untuk membantu kelancaran kerja subkomisi. Direktur Eksekutif membawahi Kepala Biro-Kepala Biro. Komnas HAM mempunyai 5 (lima) Biro yaitu Biro Pendidikan dan Penyuluhan, Biro Pengkajian Instrumen HAM, Biro Pemantauan Pelaksanaan HAM, Biro Kepustakaan Dan Dokumentasi, serta Biro Pelayanan Terpadu. Selain itu Komnas juga mempunyai bagian Hubungan Masyarakat. Komnas HAM juga telah membuka perwakilan di Daerah Istimewa Aceh dan sebelumnya juga di Timor-Timur. ${ }^{4}$

Anggota Komnas HAM (komissioner) berdasarkan Keppres Nomor 50 Tahun 1993 berjumlah 25 (duapuluhlima) orang dan untuk pertama kalinya mereka diangkat oleh Presiden. Namun berdasarkan UU No. 39 Tahun 1999 tentang HAM Pasal 83 ayat (1), komissioner berjumlah 35 (tiga puluh lima) orang yang dipilih oleh DPR berdasarkan usulan Komnas HAM dan diresmikan oleh Presiden selaku Kepala Negara. ${ }^{5}$ Masa Jabatan mereka adalah 5 (lima) tahun. Jika mekanisme

itu, arah kebijakan politik luar negeri yang turut merespon tuntutan peningkatan perlindungan HAM yang makin gencar membuat pemerintah berfikir untuk menjadikan issue Ham sebagai bagian darikebjakan dalam negeri.Baca dalam Jessica M.R. Smith, Komnas HAM and Political Of Human Rights in Indonesia (Australia: Australian National University, 1998), hlm 88.

${ }^{3}$ Profil Komnas HAM ini selengkapnya dapat dibaca pada Laporan Tahun 1999 Komnas HAM (Jakarta: Komnas HAM, 1999), hlm 6, dan Laporan Tahun 2000 Komnas HAM (Jakarta: Komnas HAM, 2000), hlm 5-6.

${ }^{4}$ Laporan Tahun 1999, Ibid., hlm 7-8.

${ }^{5}$ Menurut Laporan KOMNAS HAM tahun 2000, meskipun dalam UU No. 39/1999 tentang HAM telah diatur mekanisme pemilhan anggota komissioner namun jumlah komissioner Komnas HAM belum meneyesuaikan dengan UU No. 39/1999, dan pada saat itu jumlah komissioner, setelah dikurangi anggota yang meninggal dan yang mengundurkan diri, komissioner tinggal 18 (delapan belas) orang. Baca laporan tahun 2000 Komnas HAM, him.9. Pada pertengahan tahun 2001, Komnas HAM melalui Tim Independen yang dibentuknya telah membuka peluang bagi warga negara Indonesia yang memenuhi syarat untuk mendaftarkan diri baik secara individual maupun melalui lembaga untuk menjadi komissioner. Tecatat 547 lamaran dari masyarakat dan dari jumlah itu yang lolos seleksi Administratif sejumlah 55 orang dengam komposis 13 (tigabelas) orang dari unsur 
rekruitmen anggota Komnas HAM sesuai UU NO, 39 Tahun 1999, maka Komnas HAM akan menjadi lembaga yang representatif dan jauh akan lebih independen dibandingkan dengan penunjukan dan penganigkatan oleh Presiden.

Mulai tahun 2000, Komnas HAM bekerja dengan visi dan misi yang telah dirumuskan. ${ }^{6}$ Visi Komnas HAM adalah Hak Asasi Manusia Untuk Semua dan mempunyai misi sebagai berikut :

1. Mewujudkan lembaga yang mandiri, profesional, representatif, berwibawa, dan dipercaya oleh masyarakat nasional maupun intemasional.

2. Menegakkan, memajukan, memelihara HAM

3. Membantu menyelesäikan pëlanggaran HAM di Masyarakat

4. Menggerakkan pembangunan berwawasan HAM

5. Membangun jaringan kerjasama dengan semua pihak.

Komnas HAM dalam Peraturan

Perundang-Undangan di Indonesia

Berdasarakan Keputusan Presiden Nomor 50 tahun 1993, Komnas HAM memiliki tugas sebagai berikut:

1. Menyebarluaskan wawasan nasional dan internasional mengenai Hak Asasi Manusia baik kepada masyarakat Indonesia maupun masyrakat Intemasional

2. Mengkaji berbagai instrumen Perserikatan Bangsa-Bangsa tentang hak asasi manusia dengan tujuan memberikan saran-saran mengenai kemungkinan aksesi dan/atau ratifikasi

3. Memantau, menyelidiki pelaksanaan hak asasi manusia serta memberikan pendapat, pertimbangan dan saran kepada badan pemerintahan negara mengenai pelaksanaan hak asasi manusia

Perguruan Tinggi, 12 (duabelas) orang dari Pengacara, 5 (lima) orang pensiunan TNIPolri, 5 (lima) orang dari LSM, 4 (empat) orang dari pensiunan Jaksa, 3 (tiga) orang dari PNS, 3 (tiga) orang dari Pegawai Swasta dan 2 (dua) orang dari konsultan. Calon dari peneliti, seniman, pensiunan DPR, wartawan, Ulama, masing-masing 1 (satu) orang. Baca dalam Forum Keadilan No.27,7 Oktober 2001. Namun demikian, rekruitmen calon anggota Komnas HAM ini mendapat banyak sorotan sehubungan dengan munculnya 12 (duabelas) calon anggota tambahan sehingga jumlah calon menjadi 67 (enam puluh tuju) orang. Keduabelas anggota tambahan tersebut menjadi polemik karenamereka tidak lolos saringan dari awal. Baca berita Kompas."Calon Anggota Komnas HAM Mendadak Jadi 67 Orang". Jumat 19 Oktober, 2001. Pemilihan anggota KOMNAS HAM (komissioner) yang sesuai dengan UU No. $39 / 1999$ baru dapat direalisasikan mulai.pertengahan tahun 2002 dan padatahun 2002 ini terpilih sebagai ketua KOMNAS HAM adalah Abdul Hakim Garuda Nusantara, seorang advokat dan pembela HAM serta aktivis organisasi non pemerintah ELSAM.

${ }^{6}$ Visi dan Misi komnas HAM baru dirumuskan tahun 2000 sebagai hasil dari Lokakarya Perencanaan Strategis Komnas HAM Tahun 2000. Visi dan Misi ini memperjelas keberadaan Komnas HAM sebagai lembaga Independen dalam penegakan HAM di Indonesia. 
4. Mengadakan kerjasama regional dan internasional dalam rangka memajukan dan melindungi hak asasi manusia.

Daya kerja Komnas HAM semula mengundang berbagai keraguan dikarenakan berbagai alasan :?

1. Dibentuk hanya berdasarkan Keppres

2. Kewenangan hanya memantau dan menyelidiki. Tidak dijelaskan dan ditegaskan prosedur bagaimana luas lingkup kegiatannya.

3. Kewenangannya hanya sebatas memberikan pendapat, pertimbangan dan saran kepada pemerintah.

Meskipun hanya berdasarkan Keppres, dalam perjalanannya Komnas HAM telah dapat menjalankan perannya untuk memantau kondisi HAM dan melakukan penyelidikan atas kasus-kasus pelanggaran HAM. Setidaknya dari catatan Komnas HAM ada beberapa kasus yang dapat dijadikan bukti bagi kesungguhan Komnas HAM dalam upaya menegakkan HAM di Indoesia. ${ }^{8}$

Landasan kerja bagi Komnas HAM yang hanya berdasarkan Keppres Nomor 50 Tahun 1993 tampaknya banyak digugat banyak pihak. Komnas HAM sendiri melalui laporannya di tahun 2000 menyatakan: 9

"kalau hanya dengan mendasarkan pada keputusan Presiden saja, maka Komnas
HAM tidak mungkin dapat mengungkapkan semua bentuk pelanggaran hak asasi manusia tersebut karena Komnas HAM tidak mempunyai kekuatan mandat untuk menanganinya."

Kemudian pada tahun 1998, lahirlah sebuah Ketetapan MPR RI yang sedikit memperkuat landasan yuridis bagi perlindungan dan penegakan HAM pada umumnya dan secara khusus menguatkan keberadaan Komnas HAM. Menurut Ketetapan MPR RI No. XVII/MPR/ 1998 Pasal 4, Komnas HAM diberikan tanggungjawab untuk melakukan penyuluhan, pengkajian, pemantauan,penelitian dan mediasi tentang hak asasi manusia.

Lembaga yang diberi kewenangan untuk memberi perhatian pada masalah hak asasi manusia menurut Ketetapan MPR tersebut sebenarnya tidak hanya Komnas HAM melainkan juga lembaga-lembaga Tinggi Negara dan seluruh Aparatur Pemlerintah sebagaimana disebutkan pada Pasal 1 Ketetapan MPR tersebut yang berbunyi:

"Menugaskan kepada Lembaga-lembaga Tinggi Negara dan seluruh Aparatur Pemerintah, untuk menghormati, menegakkan dan menyebarluaskan pemahaman mengenai hak asasi manusia kepada seluruh masyarakat".

Pasal 1 TAP MPR RI No.XVII/MPR/1998 itu menegaskan bahwa tanggungjawab dalam

\footnotetext{
7 Komnas HAM. "Peranan dan Kedudukan Komnas HAM Sesusi dengan TAP MPR No. XVIIMPR/1998 tentang Hak Asasi Manusia", makalah dalam seminarmemperingati 50 tahun PIAGAM HAM, diselenggarakan oleh Universitas Kristen Indonesia, (Jakarta, 16 Desember 1998), hlm 4.

${ }^{8}$ Beberapa contoh kasus yang dapat ditangani Komnas HAM antara lain Peristiwa Liquisa 12 Januri 1995 , Kasus terbunuhnya Marsinah, seorang buruh yang tewas mengenaskan di Sidoarjo Jawa Timur, Proses litigasi terhadap Dwi Sumadji selaku tesangka dari kasus terbunuhnya wartawan Udin di Bantul Yogyakarta, Kasus tanah di dusun Tanjungsari, Kabupaten Lampung Utara. Ibid.

${ }^{9}$ Laporan Tahun 2000 Komnas HAM, op.cit., him 5.
} 
menumbuhkan kesadaran akan penghargaan dan perlindungan HAM berada di pundak segenap elemen bangsa. Jadi penegakan HAM tidak hanya menjadi tanggungjawab Komnas HAM semata.

Meskipun telah ada penegasan tugas Komnas HAM dalam Ketetapan MPR, namun Ketetapan MPR tersebut merupakan instrumen yang tidak langsung mempunyai kekuatan praktis. Maka dari itu, instrumen tersebut belum mampu memberi jaminan legal bagi kerja Komnas HAM selanjutnya.

Kekuatan dan kepastian hukum bagi kerja Komnas HAM selanjutnya baru terjadi pada tahun 1999 ketika diundangkan UU No 39 Tahun 1999 tentang Hak Asasi Manusia. Dalam Pasal 1 angka 7 UU No 39/1999 disebutkan bahwa:

"Komisi Nasional Hak asasi Manusia adalah lembaga mandiri yang kedudukannya setingkat dengan lembaga negara lainnya yang berfungsi melaksanakan pengkajian, penelitian, penyuluhan, pemantauan, atau mediasi hak asasi manusia".

Dari ketentuan di atas, dapat dilakukan suatu penelaahan tentang Komnas HAM dalam struktur organisasi negara. Pertama, Komnas Ham merupakan lembaga mandiri. Suatu lembaga yang mandiri dapat diinterpretasikan sebagai lembaga yang bekerjá tanpa campur tangan dari lembaga lainnya. Mengikuti teori trias politica, dalam struktur ketatanegaraan yang konvensional, hanya ada satu lembaga yang bekerjanya mandiri yaitu lembaga peradilan. Kedua, kedudukan Komnas HAM setingkat dengan lembaga negara lainnya. Dalam Pasal 1 angka 7 tidak disebutkan apa yang dimaksud lembaga negara itu merupakan lembaga tinggi negara, Jika demikian, maka dalam sistem ketatanegaraan $\mathrm{Rl}$, lembaga tinggi negara tidak hanya DPR, Presiden, DPA, BPK dan MA saja. Komnas HAM menjadi salah satu lembaga tinggi negara yang kedudukannya sejajar dengan lembaga-lembaga tinggi tersebut. Oleh karena itu, sebagaimana lembaga-lembaga tinggi lainnya, Komnas HAM harus melakukan Progress Report di depan lembaga tertinggi negara, yaitu MPR. Ketiga, dari sudut fungsinya, Komnas HAM menjalankan fungsi negara dibidang hak asasi manusia dengan kewenangan melakukan pengkajian, penelitian, penyuluhan, pemantauan, atau mediasi. Fungsi ini apabila dilihat dari teori pemisahan kekuasaan klasik belum begitu jelas terdapat di dalam lembaga apa. Namun demikian, dilihat fungsi yang diberikan undangundang, maka Komnas HAM menjalankan fungsi yang spesifik dibidang HAM. Sehingga Komnas HAM menjalankan fungsi eksekutif di bidang penegakan dan pemajuan HAM dan kewenangan itu diberikan oleh UU.

Pada bab Vll, Pasal 75 hingga Pasal 99 UU No 39/1999 terdapat pengaturan Komnas HAM secara lebih rinci baik dari segi kewenangannya maupun dari segi organisasi kelembagaannya. Secara singkat pengaturan dalam pasal-pasal tersebut adalah: ${ }^{10}$

Pasal 75: tentang tujuan Komnas HAM

Pasal 76: tentang fungsi, keanggotaan, kedudukan dan perwakilan

${ }^{10}$ Disarikan dari Bab VII UU No.39/1999 tentang HAM. UU ini terdiri dari 106 Pasal, disahkan di Jakarta pada tanggal 23 September 1999 dan diundangkan di Jakarta pada tanggal 23 September 1999 melaui Lembaran Negara Republik indonesia Tahun 1999 Nomor 165, Tambahan Lembaran Negara Republik Indonesia Nomor 3886 . 
Komnas HAM di Daerah

Pasal 77: tentang asas

Pasal 78: tẹntang kelengkapan Komnas HAM dan Sekretariat Jenderal

Pașal 79:tentang Sidang Paripurna

Pasal 80: tentang Sub komisi

Pasal 81: tentang tugas Sekretariat Jenderal, struktur dan mekanisme pemilihan Sekjen

Pasa 82: tentang ketentuan Sidang Paripuma dan Subkomisi dalam Peraturan Tata tertib

Pasal 83: tentang keanggotaan, strukutur pimpinan,pemilihan pimpinan dan masa jabatannya

Pasal 84:tentang persyaratan menjadi anggota Komnas HAM

Pasal 85:tentang pemberhentian anggota Komnas HAM

Pasal 86:tentang tata cara pemilihan, pengangkatan serta pemberhentian anggota meialui Peraturan Tata Tertib Komnas HAM

Pasal 87: tentang kewajiban dan hak setiap anggota Komnas HAM

Pasal 88:tentang Aturan lebih lanjut mengenai Kewajiban dan hak anggota Komnas HAM dalam Peraturan Tata Tertib

Pasal 89:tentang tugas dan wewenang Komnas HAM dalam pengkajian dan penelitian, tentang tugas dan wewenang Komnas HAM dalam penyuluhan HAM dan tentang tugas dan wewenang Komnas HAN dalam pemantauan HAM

Pasal 90: tentang pengaduan pelanggaran HAM

Pasal 91:tentang pemeriksaan atas pengaduan kepada Komnas HAM
Pasal 92:tentang jaminan kerahasiaan dalam pengaduan

Pasal 93:tentang cara pemeriksaan pelanggaran HAM

Pasal 94: tentang kewajiban pengadu, korban dan saksi untuk memenuhi permintaan Komnas HAM

Pasal 95:tentang upaya paksa dengan bantuan ketua pengadilan dalam melakukan pemanggilan seseorang yang menolak atau tidak dapat datang untuk memberikan keterangannya

Pasal 96: tentang penyelasaian melalui mediator dari Anggota Komnas HAM dan dapat diperkuat dengan putusan Pengadilan Negeri

Pasal 97:tentang kewajiban Komnas HAM menyampaikan laporannya kepada DPR dan Presiden dengan tembusan kepada Mahkamah Agung.

Pasal 98:tentang anggaran Komnas HAM yang dibebankan kepada APBN

Pasai 99:tentang Aturan lebih lanjut mengenai cara pelaksanaan fungsi, tugas, dan wewenang Komnas HAM dalam Peraturan Tata Tertib Komnas HAM.

Fungsi Kominas HAM secara terperinci juga terdapat di dalam pasal 89 UU No.39 Tahun 1999. Fungsi tersebut secara sistematis terbagi ke dalam tiga bidang yaitu bidang pengkajian dan penelitian, bidang penyuluhan, pemantauan dan bidang mediasi.

1. Fungsi bidang pengkajian dan penelitian (Pasal 89 ayat (1)):

a. pengkajian dan penelitian berbagai instrumen internasional hak asasi manusia dengan tujuan memberikan 
saran- saran mengenai kemungkinan aksesi dan atau ratifikasi

b. pengkajian dan penelitian berbagai peraturan perundang-undangan untuk memberikan rekomendasi mengenai pembentukan, perubahan, dan pencabutan peraturan perundang-undangan yang berkaitan dengan hak sasi manusia

c. penerbitan hasil pengkajian dan penelitian

d. studi kepustakaan, studi lapangan dan studi banding di negara lain mengenai hak asasi manusia

e. pembahasan berbagai masalah yang berkaitan dengan perlindungan, penegakan, dan pemajuan hak asasi manusia; dan

f. kerjasama pengkajian dan penelitian dengan organisasi, lembaga, atau pihak lainnya, baik tingkat nasional, regional, maupun internasional dalam bidang hak asasi manusia.

2. Fungsi di bidang penyuluhan (Pasal 89 ayat(2))

a. penyebarluasan mengenai hak asasi manusia kepada masyarakat

b. upaya peningkatan kesadaran masyarakat tentang hak asasi manusia melalui lembaga pendidikan formal maupun non formal serta berbagai kalangan lainnya; dan

c. kerjasama dengan organisasi, lembaga, atau pihak lainnya,baik ditingkat nasional, regional, maupun internasional dalam bidang hak asasi manusia

3. Fungsi di bidang pemantauan (Pasal 89 ayat (3))

a. pengamatan pelaksanaan hak asasi manusia dan penyusunan laporan hasil pengamatan tersebut

b. penyelidikan dan pemeriksaan terhadap peristiwa yang timbul dalam masyarakat yang berdasarkan sifat atau lingkupnya patut diduga terdapat pelanggaran hak asasi manusia

c. pemanggilan kepada pihak pengadu atau korban maupun pihak yang diadukan untuk dimintai dan didengar keterangannya

d. pemanggilan saksi untuk diminta dan didengar kesaksiannya dan kepada saksi pengadu diminta menyerahkan bukti yang diperlukan

e. peninjauan di tempat kejadian dan tempat lainnya yang dianggap perlu

f. pemanggilan terhadap pihak yang terkaituntukmemberikan keterangannya secara tertulis atau menyerahkan dokumen yang diperlukan sesuai dengan aslinya sengan persetujuan Ketua Pengadilan.

g. pemeriksaan setempat terhadap rumah, pekarangan, bangunan, dan tempat-tempat lainnya yang diduduki atau dimiliki pihak tertentu dengan persetujuan Ketua Pengadilan

h. pemberian pendapat berdasarkan persetujuan Ketua Pengadilan terhadap perkara terteritu yang sedang dalam proses peradilan, bilamana dalam perkara tersebut terdapat pelanggaran hak asasi manusia dalam masalah publik dan acara pemeriksaan oleh pengadilan yang kemudian pendapat Komnas HAM tersebut wajib diberitahukan oleh hakim kepada para pihak.

4. Fungsi di bidang mediasi (Pasal 89 ayat 
13(4))s Komnas" HAM , bertugas dan berwenang melakukanmo a mor

a. perdamaian kedua belah pihak

b. penyelesaian perkara melaui cara konsultasi, negosiasi, mediasi, konsiliasi, dan penilaian ahli.

c. pemberian saran kepada para pihak untuk menyelesaikan sengketa melalui pengadilan

d. penyampaian rekomendasi atas suatu kasus pelanggaran hak asasi manusia kepada pemerintah untuk ditindaklanjuti; dan

e. penyampaian rekomendasi atas suatu kasus pelanggaran hak asasi. manusia kepada Dewan Perwakilan Rakyat Indonesia untuk ditindaklanjuti

Pengaturan Komnas HAM dalam UU No 39/1999 cukup komprehensif, Namun demikian, apabila lémbaga ini akan disejajarkan dengan lembaga negara lainnya, maka sudah seharusnya Komnas HAM memiliki UU tersendiri yang mengatur segala hal ihwal mengenai Komnas HAM sebagaimana lembagalembaga negara yang lainnya juga diatur dengan UU tersendiri."

Kemudian, di dalam UU No. 26 tahun 2000 tentang Pengadilan HAM, ${ }^{12}$ Komnas juga diberi kewenangan untuk menyelidiki pelangggaran HAM berat, sebagaimana terdapat di dalam Bagian keempat, Pasal 18 hingga Pasal 20. Pasal
18 menegaskan bahwa peneyelidikan pelanggaran HAM berat dilakukan oleh Komnas HAM dan Komnas HAM untuk keperluan itu dapat membentuk tim ad Hoc yang terdiri dari unsur Komnas HAM dan masyarakat.

Selengkapnya, kewenangan penyelidikan yang diberikan kepada Komnas HAM dalam UU No. 26 tentang Peradilan HAM sebagai berikut:

Pasal 18

(ayat (1)): Penyelidikan terhadap pelanggaran HAM yang berat dilakukan oleh Komisi Nasional Hak Asasi Manusia

(ayat (2)): Komisi Nsional Hak asasi Manusia dalam melakukan penyelidikan sebagaimanaa dimaksud dalam ayat (1) dapat membentuk tim ad hoc yang terdiri atas Komisi Nasional Hak Asasi Manusia dan unsur masyarakat.

Pasal 19

(ayat (1)): Dalam melaksanakan penyelidikan sebagaimana dimaksud dalam Pasal 18, penyelidikan berwenang:

a. melakukan penyelidikan dan pemeriksaan terhadap peristiwi yang timbul dalaam masyarakat berdasarkan sifat atau lingkupnya

\footnotetext{
"Usulan tentang UU tentang Komnas HAM sebenarnya sudah menjadi agenda tersendiri bagi Komnas HAM. Dalm seminar memperingati 50 Tahun Piagam HAM di UKI Jakarta, 16 Desember 1998, Komnas HAM telah melontarkan gagasan tentang RUU Komnas HAM. Namun akhirnya pengaturan Komnas HAM hanya disisipkan dalam UU No. 39 Tahun 1999 tantang Hak Asasi Manusia dan UU No. 26 Tahun 2000 tentang Peradilan Hak Asasi Manusia.

${ }^{12}$ UU No. 26 Tahun 2000 terdiri dari 51 Pasal, disahkan di Jakarta pada tanggal 23 Nopember 2000 dan diundangkan pada tanggal 23 Nopember 2000 melalui Lembaran Negara Republik Indonesia Tahun 2000 Nomor 208 dan Tambahan Lembaran Negara Republik Indonesia Nomor 4026.
} 
yang patut diduga terdapat pelanggaran hak asasi manusia yeng berat;

b. menerima laporan atau pengaduan dari seseorang atau kelompok orang tentang tejiadinya pelanggaran hak asasi manusia yang berat, serta mencari keterangan dan bukti;

c. memanggil pihak pengadu, korban atu pihak yang diadukan untuk diminta dan didengar keteraangannya;

d. memanggil saksi untuk diminta dan didengar kesaksiannya;

e. meninjau dan mengumpulkan keterangan di tempat kejadian dan tempat lainnya yang dianggap perlu;

f. memanggil pihak terkait untuk memberikan keterangan secara . tertulis atau menyerahkan dokumen yang diperlukan sesuai dengan aslinya;

g. atas perintah penyidik dapat melakukan tindakan berupa;

1). pemeriksaan surat;

2). penggeledehan dan penyitaan;

3). Pemeriksaan setempat terhadap rumah, pekarangan, bangunan, dan tempat-tempat lainnya yang diduduki atau dimiliki pihak tertentu;

4). Mendatangkan ahli dalam hubungan dengan penyelidikan.

(ayat (2)): dalam hal penyelidik mulai melakukan penyelidikan suatu peristitiwa yang diduga merupakan pelanggaran hak asasi manusia yang berat penyelidik memberitahukan hal itu kepada penyidik.
Pasal 20

(ayat (1)): Dalam hal Komisi Nasional Hak Asasi Manusia berpendapat bahwa terdapat bukti permulaan yang cukup telah terjadi peristiwa pelanggaran hak asasi manusia yang berat, maka kesimpulan hasil penyelidikan disampaikan kepada penyidik.

(ayat (2)): Paling lambat 7 (tujuh) hari kerja setelah kesimpulan hasil penyelidikan disampaikan, Komisi Nasional Hak Asasi manusia menyerahkan seluruh hasil penyelidikan kepada penyidik.

(ayat (3)): Dalam hal penyidik berpendapat bahwa hasil penyelidikan sebagaimana dimaksud dalam ayat (2) masih kurang lengkap, penyidik segera mengembalikan hasil penyelidikan tersebut kepada penyelidik disertai petunjuk untuk dilengkapi dan dalaam waktu 30 (tiga puluh) hari sejak tanggal diterimanya hasil penyelidikan, penyelidik wajib melengkapi kekurangan tersebut.

Melihat ketentuan dalam Pasal 18 hingga Pasal 20 UU No. 26 Tahun 2000, maka kewenangan Komnas HAM menjadi semakin luas. Dengan demikiaan peran yang diberikan kepada Komnas HAM menjadi semakin berat, dalam arti Komnas HAM ternyata tidak sekedar menjadi lembaga penyuluh kesadaran akan $\mathrm{HAM}$, atau lembaga yang menerima pengaduan pelanggaran HAM dan melakukan mediasi, namun Komnas HAM sudah masuk dalam wilayah kerja dalam sistem peradilan pidana yaitu Komnas HAM menjalankan sebagian dari tugas Polisi selaku penyelidik.

Peran tersebut menjadi sangat signifikan dengan harapan masyarakat yang begitu antusias menyambut dengan keberadaan Komnas HAM sejak awal berdirinya. Secara 
sosiologis Komnas HAM dapat menjälankan peran yang diharapkan oleh masyarakat atau dalam teori tentang role dari Soerjono Soekanto, Komnas HAM dapat-menjalankan ideal, prescribed role. ${ }^{13}$

Di samping itu, kerja Komnas HAM yang kini telah berjalan sesuai amanat undangundang seperti melakukan penyelidikan atas berbagai kasus pelanggaran HAM seperti kasus pelanggaran HAM Tanjung Priok, kasus pelanggaran HAM berat di Aceh, di TimorTimur, di Maluku dan di Sampit, akan semakin meneguhkan peranan Komnas HAM dalam kenyataan atau dalam teori role disebut performed, actual role. ${ }^{14}$

Dari kewenangan Komnas HAM baik yang diberikan oleh UU No. 39 Tahun 1999 tentang Hak Asasi Manusia maupun oleh UU No. 26 Tahun 2000 tentang Peradilan HAM yang meliputi peran dalam bidang penelitian dan pengkajian, penyuluhan, pemantauan, mediasi dan penyelidikan sebagaimana telah diuraikan dalam bagian kedua bab ini, maka dilihat dari cakupan role yang dikemukakan oleh Pumadi Purbacaraka dan Soejono Soekanto, ${ }^{15}$ Komnas HAM telah menjadi lembaga publik yang memiliki kekuasaan, public services, kebebasan dan kewajiban terhadap kepentingan umum.

Melihat peran tersebut, maka Komnas HAM harus mempunyai staf-staf yang mempunyai kemampuan untuk melakukan investigasi sebagaimana yang dimiliki oieh polisi.

\section{Komnas HAM dalam Struktur Ketatanegaraan Indonesia}

Jika meninjau sejarah pembagian kekuasaan, maka keberadaan teori Montesquieu menjadi sangat krusial sebab hampir semua konsep pembatasan kekuasaan dalam struktur ketatanegaraan suatu negara berpijak pada teorinya. Amerika serikat merupakan negara pertama yang mengadopsi teori Montesquieu dalam konstitusinya.

Pembatasan kekuasaan di Indoensia yang tercermin dalam konstitusinya, terutama UUD 1945 juga mencerminkan adanya teori Monetsquieu. Apabila kita meruntut sejarah pada saat pembicaraan mengenai Rancangan UUD di BPUPKI tampak teori ini disinggung oleh para founding fathers. Dalam sidangnya tanggal 11 Juli 1945, Maramis melontarkan gagasan uitvoerende macht, wetgevende macht dan. rechtelijke macht atau yang sering disebut sebagai Trias Politika supaya dciptakan dalam UUD Indoensia. Selengkapnya pendapat Maramis adalah:

"Saya berpendapat bahwa dalam preambule sudah ditetapkan semua dasar. Jadi, saya minta supaya preambule itu dibicarakan dan atas preambule itu didirikan hukum dasar. Saya berpendapat bahwa dengan Preambule kita tidak periu menyusun dasar dengan panjang lebar. Dalam pandangan saya asal pemerintah berjalan, kita sudah senang, artinya polisi, 47-48.

${ }^{13}$ Soerjono Soekanto, Beberapa Aspek Sosio Yuridis Masyarakat (Jakarta: Penerbit Alumni; 1983), hlm

$14 \mathrm{fbid}$.

${ }^{15}$ Purnadi Purbacarakan dan Soerjono Soekanto mengemukan konsep role dari suatu subyek di dalam negara atau yang dimiliki oleh suatu lembaga, badạn, organisasi, pejabat dan warga negara mencakup soal kekuasaan, public services, kebebasan dan kewajiban tehadap kepentingan umum. Baca Pumadi Purbacaraka dan Soerjono Soekanto, Menelusuri Sosiologi Hukum Negara (Jakarta: Rajawli Press, 1993), hlm 38. 
kehakiman dan Pangreh Pradja kalau sudah disusun serapih-rapinya, masyarakat sudah berjalan. Oleh karena itu saya mengusulkan disini supaya sesudah panitia kecil menerima preambule sebagai dasar dari hukum dasar, kita ciptakan disini tentang uievoerende macht, wegevende macht, dan rechtelijke macht. Jadi, mengingat tiga pasal dari Trias Politica, sebab yang lain toh tidak bisa dijalankan. ${ }^{n 16}$

Maramis memberikan sinyalemen bahwa substansi. UUD yang sedang dirancang pada saat itu harus menetapkan pembagian dan pembatasan kekuasaan terutama kekuasaan menjalankan undang-undang (uitvoerende macht), kekuasaan membuat undang-undang (wetgevende macht) dan kekuasaan mengadili (rechtelijke macht). Bagi Maramis, Trias Polica itu dulu ditetapkan, sebab itulah yang perlu dan dengan ádanya tiga hal tersebut, masyarakat bisa berjalan. ${ }^{17}$

Namun ide Maramis tidak bergulir dengan tanpa hambatan. Artinya, usul Maramis menjadi perdebatan di kalangaan anggota BPUPKI yang hadir pada saat itu. Soekarno, misalnya menanyakan apakah ketiga lembaga yang ditutarakan Maramis itu sudah cukup untuk menjalankan keadilan sosial? ${ }^{18}$ Soekamo selanjutnya menyatakan bahwa Rusia telah menolak Trias Politica, demikian juga Sun Yat Sen. Ada pula yang menganggap Trias Politica itu kolot. ${ }^{19}$ Soepomo menambah pendapat Soekamo dengan pemyataan:

"Sekarang yang menjalankan cuma Amerika sendiri, meskipun aliran itu timbul di Perancis tetapi di Eropa Barat tidak dijalankan dengan consequent. Jadi dengan maksud itu yang menjalankan pekerjaan negara tidak bisa dipisah dengan principieel dari kekuasan pemerintahan. Sebab dalam praktik juga badan yang membikin undang-undang diseriahi juga pekerjaan pemerintahan, kehakiman juga juga diserahi 'pekerjaan pemerintahan dan pemerintah juga diberi kekuasaan membikin undang-undang. Oleh karena itu menurut para ahli tidak cocok dengan praktik"20

Inti dari perdebatan tersebut adalah bahwa Trias Politica dijalankan tidak selalu dengan pemisahan kekusaan secara murni tetapi juga dijalankan dengan pembagian kekuasaan sehingga ada lembaga yang dapat bekerja sama untuk satu kewenangan.

Pada akhimya, Trias Politica menjadi inspirasi pembagian kekuasaan dalam UUD 1945. Namun UUD 1945 tidak menganut pemisahan secara tegas sebab ada satu kewenangan yang diserahkan pada dua lembaga, misalnya kekuasaan membuat undang-undang yang ada pada parlemen dan Presiden. Disamping itu, UUD 1945 tidak hanya mengenal tiga lemabaga negara yang secara formal disebut secara

${ }^{16}$ Pendapat Maramis dalam sidang BPUPKI, tepatnya pada rapat panitia hukum dasar tanggal 11 Juli 1945. Dikutip dari Risalah Sidang BPUPKI dan PPKI 28 Mei 1945 dan 22 Agustus 1945, Sekretariat Negara Republik Indonesia, (Jakarta, 1998), hlm 234.

\footnotetext{
${ }^{17}$ bid., hlm 242.

${ }^{18} \mathrm{Ibid}$

${ }^{19} \mathrm{lbid}$. hlm 245.

$20 \mathrm{lbid}$
} 


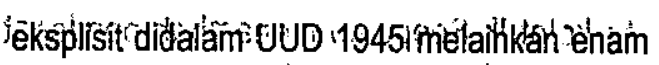

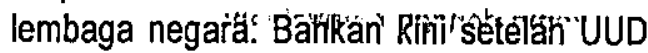
1945 mengalami amandemen tiga kali, lembaga negara yang langsung disebut dalam konstitusi, terutama setelah amandeman ketiga ada tujuh lembaga ada tujuh dengan tambahan Mahkamah Konstitusi.

Konsep Trias Politica dengan pemisahan kekuasaan secara tegas menjadi pilihan yaing penting ketika hampir kekuasaan negara di dunia terletak pada satu tangan. Ide Montesquieu adalah agar tidak terjadi penyalahgunaan kewenangan sehingga kekuasaan negara perlu dipisah dan dibatasi.

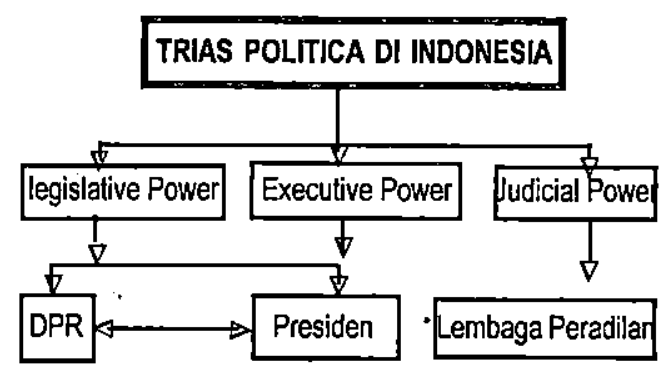

Di Indoensia, pemisahan kekuasaan secara tegas memang tidak dianut. Hal ini terlihat dari fungsi legislative yang dijalankan oleh dua lembaga yaitu DPR dan Presiden. Keduanya sesuai dengan UUD 1945 harus bekerja sama dalam membuat undangundang.

A. Hamid S Attamimi menegaskaan bahwa UUD 1945 dan Sistem Pemerintahan Negara yang diwujudkanya tidak membagi kekuasaan negara menurut trias pòlitika, yaitu kekuasaan yang semata-mata membentuk peraturanperaturan, yang semata-mata melaksanakannnya dan, kekuasaan yang mengadili sengketasengketa yang timbul akibat pelaksanaan peraturan-peraturan. UUD 1945 menganut sistem sendiri sesuai dengan teori bernegara bangsa Indonesia. ${ }^{21}$

Ketentuan tentang kerjasama antar lembaga negara tersebut kemudian dipertegas dengan TAP MPR No. II//MPR/1978 tentang Kedudukan dan Hubungan Tata Kerja Lembaga Tertinggi Negara Dengan/Atau Antar Lembaga Tinggi Negara.

Kedudukan selalu berkaitan dengan posisi dalam suatu sistem yang biasanya menunjuk pada tempat-tempat vertikal. Setidaknya itu yang dikemukakan oleh Soerjono Soekanto dalam konsepnya tentang kedudukan. ${ }^{22}$ Dalam bagan tersebut di atas belum tampak kedudukan Komnas HAM secara vertikal ada pada lembaga yang mana. Penulis mencoba mendiskripsikan kedudukan Komnas HAM dari sudut beberapa bentuk hukum yang mendasarinya. Pertama, dari sudut pandang Keppres № 50 Tahun 1993 dimana komnas HAM merupakan lembaga bentukan Presiden. Konsekwensinya, Komnas HAM secara vertikal ada pada lembaga yang membentuknya. Dengan demikian dalam bekerjanya dan pertanggungjawabannya Komnas HAM melakukan hal itu di bawah pengawasan Presiden. Kedua, dari sudut TAP. MPR No. XVII/MPR/1998. Dalam Tap ini ditegaskan bahwa Komnas HAM sejajar dengan lembaga tinggi negara lainnya. Dengan demikian,

${ }^{21}$ A. Hamid S. Attamimi dalam Disertasi Doktor berjudul "Peranan Keputusan Presiden Republik Indonesia Dalam Penyelenggaraan Pemerintahan Negara, Suatu Studi Analisis Mengenai Keputusa Presiden Yang Berfungsi Pengaturan Dalam Kurun Waktu Pelita I-Pelita IV' (Jakarta: Universitas Indonesia, 1990), hlm 33.

22 Soerjono Soekanto, op.cit. 
posisi vertikal Komnas ada di bawah MPR sebagaimana lembaga tinggi negara lainnya dalam setruktur ketatanegaraan Rl berdasarkan UUD 1945 sebelum di amandemen. Ketiga, dari sudut undang-undang pembentukannya. Oleh karena Komnas HAM mendapat peran atau fungsi yang diberikan oleh produk legislative, yaitu UU, terutama UU No. 39 Tahun 1999 tentang Hak Asasi Manusia dan UU No. 26 Tahun 2000 tentang Pengadilan Hak Asasi Manusia, maka Komnas HAM harus menjalankan perintah undang-undang. Tugas untuk menjalankan peran sesuai dengan apa yang teiah diatur oleh undang-undang diawasi oleh DPR. ${ }^{23}$ Sehingga secara vertikal posisi Komnas HAM berada pada lembaga yang mengeluarkan UU. Mengingat UU di Indonesia dibuat oleh DPR bersama Presiden maka ada dua lembaga yang secara tidak langsung mengawasi Komnas HAM yaitu Presiden dan DPR. Namun demikian, dilihat dari sifat kelembagaan Komnas HAM yang independent maka sudah sepatutnya DPR yang melakukan pengawasan. Mengapa DPR? Hal itu disebabkan DPR merupakan representasi seluruh rakyat Indonesia sehingga sudah sewajarnya lembaga yang melakukan pelayanan publik di awasi oleh parlemen. Akan tetapi dalam Pasal 1 angka 7 UU No. 39 tahun 1999 ditegaskan bahwa kedudukan Komnas HAM setingkat dengan lembaga tinggi negara yang lain. Dengan demikian posisi vertikal Komnas HAM tidak merupakan. subordinat atau under dari lembaga tinggi lainnya melainkan neben dengan lembaga tinggi yang lain. Namun demikian, dari sudut pemilihan anggota Komnas HAM menurut UU No 39 Tahun 1999 Pasal 83 ayat (1) dilakukan oleh DPR dan diresmikan oleh Presiden, maka Komnas HAM berada dalam pengawasan parlemen. Adapun peran Presiden adalah melakukan tindakan administratif yaitu meresmikan dalam Keputusan Presiden. Peresmian melalui Keppres itu dilakukan untuk menjaga kemandirian Komnas HAM sebagaimana dijelaskan dalam penjelasan Pasal 83 ayat (1). Selain itu dilihat dari sudut pertanggungjawabannya, menurut Pasal 97 UU No. 39 Tahun 1999, Komnas HAM harus melaporkan pelaksanaan fungsi, tugas dan kewenangannya kepada DPR dan Presiden dengan tembusan kepada Mahkamah Agung. Maka ada dua lembaga yang secara langsung berkompeten dalam soal pertanggungjawaban Komnas HAM yaitu DPR dan Presiden. Dengan demikian, UU No. 39 Tahun 1999, menjadikan dualisme posisi vertikal Komnas HAM. Pertama, jika berangkat dari Pasal 1 angka 7 maka posisi vertikal Komnas HAM sejajar dengan lembaga tinggi negara yang lainnya. Sedangkan dilihat dari prosedur pemilihan anggota (Pasal 83 ayat (1)) dan pertanggungjawabannya (Pasal 97) maka posisi vertikal Komnas HAM ada pada dua lembaga yaitu DPR dan Presiden. Setidaknya ini dilihat dari bentuk hukum yang mendasari Komnas HAM.

Kedudukan Komnas HAM juga dapat dikaji dari sudut pandang fungsi yang dijalankannya. Menurut UU No. 39 Tahun 1999 tentang HAM, teruatama Pasal 89 ayat (4) Komnas HAM mempunyai fungsi Mediasi yang

${ }^{23}$ Fungsi DPR dalam prakteknya tidak hanya menjalankan fungsi legislative yaitu membuat undangundang, namun DPR sebagai parlemen yang anggotanya merupakan representasi darikonstituennya, melakukan fungsi pengawasan terhadap jalannya pemerintahan. 


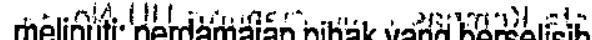
meliputi: perdạmaálan pihäk yang berselisish dan penyelesaian perkara melalui konsultasi, mediasi, negosiasi, konsiliasi dan penilaian para ahli, maka Komnas HAM menjalankan sebagian kecil fungsi peradilan, sebab langkah-langkah tersebut, terutama perdamaian para pihak yang berselisih, konsiliasi dan penilaian para ahli terhadap suatu kasus juga dilakukan oleh lembaga peradilan. ${ }^{24}$ Kemudian berdasarkan UU No 26 Tahun 2000 tentang Pengadilan HAM terutama Pasal 18. 19 dan 20, Komnas HAM menjalankan fungsi penyelidikan terhadap kasus pelanggaran HAM berat. Berdasarkan fungsi-fungsi tersebut, maka kedudukan Komnas HAM berada pada sistem peradilan.

Penentuan kedudukan Komnas HAM dalam struktur ketatanegaraan RI berdasarkan hat-hàl yang telah diuraikan di atas menunjukkan posisi yang beragam. Berdasarkan hukum yang membentuknya, posisi Komnas HAM, pertama berada di bawah lembaga kepresidenan, kedua berada sejajar dengan lembaga tinggi negara yang lainnya, dan ketiga ada dibawah lembaga legislative. Kemudian berdasarkan berdasarkan fungsi.mediasi dan penyelidikan, posisi Komnas HAM berada pada lingkaran struktur lembaga peradilan.

Dibawah Keppres No 50 Tahun 1993 Komnas HAM merupakan lembaga yang dibentuk oleh Presiden dalam kapasitasnya sebagai kepala eksekutif. Secara teoritis, kewenangan Presiden membentuk Komnas HAM melalui Keputusan Presiden, merupakan kewenangan penuh sebagai penyelenggara pemerintahan. Jellinek mengatakan bahwa kewenangan penyelenggaraan pemerintahan secara formal mengandung unsur mengatur dan memutus dan secara material mengandung unsur memerintah dan menyelenggarakan. ${ }^{25}$ Dalam dimensi ini fungsi yang diperankan Komnas seperti fungsi mengadakan gerakan penyadaran HAM melalui penelitian, penyuluhan dan pelatihan secara luas - tidak terlepas dari unsur turut menyelenggarakan pemerintahan. Sehingga kedudukan Komnas juga berada dibawah lembaga eksekutif. Sementara itu, dalam fungsi mediasi dan penyelidikan, Komnas HAM menjalankan fungsi semi judicial, sehingga secara tidak langsung Komnas HAM mempunyai hubungan dengan institusi peradilan.

Fungsi semi judicial ini merupakan kewenangan sub-poena dimana Komnas mempunyai kewenangan investigasi. Namun demikian, kewenangan ini sesungguhnya mempunyai standar intemasional. ${ }^{26}$

\section{Simpulan}

Komnas HAM merupakan the body state yang dimaksudkan bekerja secara independen. Jaminan independensi Komnas HAM itu harus dimulai dari posisi vertikal yang jelas dalam struktur ketatanegaraan. Melihat beberapa

${ }^{24}$ Fungsi yang dimaksud tidak untuk semua jenis perkara sebab dalam sistem hukum di Indonesia, untuk perkara-perkara Pidana, fungsi penyelesaian dengan cara perdamaian, apalagi negosiasi dan konsiliasi hampir tidak pemah dilakukan. Fungsi tersebut lebih banyak dipraktekkan pada perkara yang bersifat keperdataan.

${ }^{25}$ Pendapat Jellinek sebagaimana dikutip oleh A Hamid S. Attamimi.Op.Cit. hlm 32.

${ }^{20}$ SAHRDC-HRDC, The Indonesian National Human Rights Commission: The Formative Year, SAHRDC New Delhi, India, 2000, sebagaimana diterjemahkan oleh Agung Yudhawiranata, Komnas HAM dan PrinsipPrinsip Paris, Sebuah Gugatan (Jakarta: Elsam, 2001), him 27. 
peráturan perundang-undangan yang menjadi dasar yuridis keberadaan Komnas HAM di Indonesia, agaknya belum cukup memberi jaminan bagi independensi komnas HAM. Bahkan dasar yuridis itu bisa jadi cụkup menyulitkan Komnas HAM untuk secara leluasa menjalankan tugas-tugasnya. Apalagi Komnas HAM tidak semata-mata bekerja atas dasar prinsip hukum nasional, tetapi juga prinsipprinsip dalam lapangan hukum Internasional yang berkaitan dengan masalah HAM. Memang independensi Komnas HAM tidak semata-mata dilihat dari dasar yuridisnya tetapi juga harus dilihat dari berbagai macam ranah, seperti anggarannya berasal dari mana, rekruitmen anggotanya bagaimana, komposisi anggotanya terdiri dari kalangan manasaja.Namun demikian; ranah-ranah tersebut pada dasarnya harus masuk dalam aturan hukum yang memberi legitimasi bagi kedudukan dan peran Komnas HAM di Indonesia.

\section{Daftar Pustaka}

Attamimi, A. Hamid S. "Peranan Keputusan Presiden Republik Indonesia Dalam Penyelenggaraan Pemerintahan Negara, Suatu Studi Analisis Mengenai Keputusan Presiden Yang Berfungsi Pengaturan Dalam Kurun Waktu Pelita . I-Pelita IV", Disertasi Doktor di Universitas Indonesia, Jakarta, 1990.

Komnas HAM. "Peranan dan Kedudukan Komnas HAM Sesusi dengan TAP MPR No. XVII/MPR/1998 tentang Hak Asasi Manusia." Makalah dalam seminar memperingati 50 tahun PIAGAM HAM. Diselenggarakan oleh Universitas
Kristen Indonesia, Jakarta: 16 Desember 1998.

,Laporan Komnas HAM

Tahun 1999, Jakarta: Komnas HAM, 1999. , Laporan Komnas HAM Tahun 2000, Jakarta: Komnas HAM, 2000.

Lay, Cornelis dan Pratikno. Komnas HAM dibawah Rezim Otoritarian, FISIPOL UGM, 1998.

Purbacarakah, Purnadi dan Soerjono Soekanto. Menelusuri Sosiologi Hukum Negara, Jakarta: Rajawali Press, 1993.

Puspitasari, Sri Hastuti. "Kedudukan dan Peran Komnas HAM dalam Struktur Ketatanegaraan Indonesia", Thesis pada Program Pascasarjana llmu Hukum Universitas Indonesia, Jakarta, 2002.

Republik Indoensia, Tap MPR No III/MPRI 1978.

1998. Tap MPR No XVI//MPRI Undang-Undang No. 39 Tahun 1999 tentang Hak Asasi Manusia. Lembaran Negara Republik Indonesia Tahun 1999 Nomor 165, Tambahan Lembaran Negara Republik Indonesia Nomor 3886.

Tahun 2000 tentang Peradilan Hak Asasi Manusia. Lembaran Negara Republik Indonesia Tahun 2000 Nomor 208 dan Tambahan Lembaran Negara Republik Indonesia Nomor 4026. 
14 . Republik Indonésia'No: 50 Tahun 1993 tentang Pembentukan Komisi Nasional Hak Asasi Manusia.

SAHRDC -HRDC, The Indonesian National Human Rights Commission: The Formative Year, SAHRDC, New Delhi, India, 2000, sebagaimana diterjemahkan oleh Agung Yudhawiranata, Komnas HAM dan Prinsip-prinsip Paris, Sebuah Gugatan, Jakarta: Elsami, 2001.
Sekretariat Negara RI, Risalah Sidang BPUPKI dan PPKI 28 Mei 1945 dan 22 Agustus 1945, Sekretariat Negara Republik Indonesia, 1998.

Smith, Jessica M.R., Komnas HAM and Political Of Human Rights in Indonesia, Australian National University, 1998.

Soekanto, Soerjono. Beberapa Aspek Sosio Yuridis Masyarakat, Jakarta: Penerbit Alumni, 1983. 